\title{
Synthesis, Spectral Studies, and Theoretical Treatment of New Ni(II), and Co(II) Complexes of Bidenetate Ligands 2- Benzamido Benzothiazole ,and 2-Actamido Benzothiazole.
}

\author{
Mahasin F. Alias* Ameena N. Seewan* \\ Received 8, October, 2012 \\ Accepted 5, December, 2012
}

\begin{abstract}
:
New metal complexes of the ligands 2-benzamido benzothiazole(B1), and 2actamido benzothiazole(B2) with metal ions $\mathrm{Ni}(\mathrm{II})$, and $\mathrm{Co}(\mathrm{II})$ were prepared in alcoholic medium. The prepared complexes were characterized by FT-IR and electronic spectroscopy, Magnetic susceptibility, Flame Atomic Absorption technique as well as elemental analysis and conductivity measurement. From the spectral studies, an octahedral monomer structure proposed for $\mathrm{Ni}$ (II) complexes, and a tetrahedral monomer structure for $\mathrm{Co}$ (II)complexes.Semi-empirical methods (PM3, and ZINDO/1)were carried out to evaluate the heat formation $\left(\Delta \mathrm{H}^{\circ}\right.$ ) binding $\operatorname{energy}\left(\Delta \mathrm{E}_{\mathrm{b}}\right)$ and dipole moment $(\mu)$ for all metal complexes. Also vibration frequencies, Electrostatic potential, HOMO and LUMO energies for ligands were calculated.
\end{abstract}

Key words: Benzamidobenzothiazole;Actamidobenzothiazole;Metal complexes.

\section{Introduction:}

The interest in coordination chemistry is increasing continuously with the synthesis and characterization of large number of transition complexes with heterocyclic ligands containing nitrogen, oxygen and sulfur donors[1].The aromatic benzothiazole nucleus is associated with a variety of antihistamine activity pharmacological actions[2]such as fungicidal[3] and leishmanicides activities[4-a]'These activities are probably due to the presence of the-N=C-S group[4b].The amide bond $[-\mathrm{C}(\mathrm{O}) \mathrm{NH}-]$ has long attracted much attention since it is an essential building unit in proteins. The high stability of the amide linkage toward hydrolysis is of crucial importance to biological systems, since it allows the construction of peptides from relatively simple amino acid precursors [5].The coordination chemistry of amide ligands is an important part of a number of chemical problems [5].

The wide range of application of the amide group ligands and its metal complexes aroused our interest to prepare a new series of some metal complexes.

\section{Material and methods:}

\section{1-General procedure for prepared}

ligands[4-a].

In around bottom flask equipped with magnetic bar stirrer a mixture of (benzyl or ethanyl chloride)(0.06 mole)and (0.06 mole) of 2-amino benzothiazole with $2 \mathrm{ml}$ of triethylamine in $25 \mathrm{ml}$ of THF was placed and refluxed for (2-3)hrs. After cooling, the excess of solvent was removed under vacuum and the solid separated was filtered and purified by dissolving at DMF or DMSO and reprecipting from water or acetone.

*Department of Chemistry, College of Science for Women, University of Baghdad-Iraq 
The steps of the synthesis of these

ligands is shown below:-

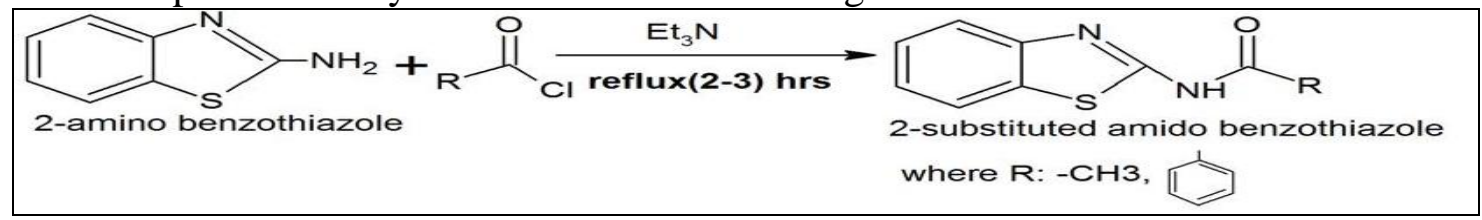

Fig(1):Scheme of synthesis for ligands(B1, and B2).

Department, College of Science,

\section{2-Preperation of ligand}

\section{B1complexes:-}

An ethanolic solution of the suitable metal salt $(1 \mathrm{mmole}$ nickel nitrate hexahydrate, and cobalt nitrate hexahydrate) was added to an ethanolic solution of $0.25 \mathrm{~g}(1 \mathrm{mmole})$ of 2benzamido benzothiazole(B1) in 1:1(ligand :metal)molar ratios, refluxed for $5 \mathrm{hrs}$, colored precipitates formed washed with distilled water, dried and recrystallized from ethanol and dried at $50^{\circ} \mathrm{C}$ Table (1) shows the physical properties of the prepared complexes.

3-Preperation of ligand B2 complexes:-These complexes were prepared by the same way as above except refluxing for $7 \mathrm{hrs}$. Table (1) shows the physical data of the prepared complexes.

\section{Instrumentation:-}

Elemental C.H.N.S analysis was carried out on a EM-017.mth instrument in laboratories of Chemistry
University of Babylon.The FT-IR spectra in the range $(4000-400) \mathrm{cm}^{-}$ ${ }^{1}$ were recorded as $\mathrm{KBr}$ disc on IRPrestige-21,Single beam path Laser, Shimadzu Fourier Transform infrared Spectrophotometer .The spectra were recorded in the laboratories of IbnSina State company, UV- Visible spectra were measured using UV-1650PC Shimadzu,UV-Visible

Spectrophotometer in range (200-950) $\mathrm{nm}$. The magnetic susceptibility values of the prepared complexes were obtained at room temperature using Magnetic Susceptibility Balance of Johnson mattey catalytic system division ,England, Atomic Absorptionmeasurements of the prepared complexes were obtained using ShimadzuAtomic Absorption 680 Flame Spectrophotometer .The Conductivity values of the prepared complexes were measured using DMF as solvent, the concentration $10^{-3} \mathrm{M}$ using(WTW)Conductometer.

Table(1):Physical data of new ligands(B1 \& B2) and their complexes .

\begin{tabular}{|c|c|c|c|c|c|c|c|c|c|}
\hline \multirow[t]{2}{*}{ Comp. } & \multirow[t]{2}{*}{ Color } & \multirow[t]{2}{*}{$m \cdot p /{ }^{\circ} c$} & \multicolumn{5}{|c|}{ Found(Calculated) } & \multirow{2}{*}{$\begin{array}{r}\text { M.Wt } \\
\text { g.mole }\end{array}$} & \multirow[t]{2}{*}{ Yield\% } \\
\hline & & & $\mathrm{C} \%$ & H\% & N\% & S\% & M\% & & \\
\hline B1 & Pale yellow & $167-168$ & $\begin{array}{c}65.28 \\
(66.14)\end{array}$ & $\begin{array}{c}3.80 \\
(3.93)\end{array}$ & $\begin{array}{c}12.31 \\
(11.02)\end{array}$ & $\begin{array}{c}13.22 \\
(12.59)\end{array}$ & |------ & 254.00 & 70.12 \\
\hline B2 & Light yellow & $188-190$ & $\begin{array}{c}55.89 \\
(56.25)\end{array}$ & $\begin{array}{c}4.60 \\
(4.16)\end{array}$ & $\begin{array}{c}13.55 \\
(14.58)\end{array}$ & $\begin{array}{c}16.66 \\
(17.43)\end{array}$ & ------ & 192.00 & 74.88 \\
\hline NiB1 & Light yellow & $120-122$ & $\begin{array}{c}30.99 \\
(31.89)\end{array}$ & $\begin{array}{c}3.93 \\
(3.79)\end{array}$ & $\begin{array}{c}9.95 \\
(10.63\end{array}$ & $\begin{array}{c}5.26 \\
(6.07)\end{array}$ & $\begin{array}{c}10.22 \\
(11.14)\end{array}$ & 544.69 & 81.25 \\
\hline CoB1 & Greenish blue & $128-130$ & $\begin{array}{c}34.48 \\
(35.50)\end{array}$ & $\begin{array}{c}2.41 \\
(2.90)\end{array}$ & $\begin{array}{c}10.84 \\
(11.80)\end{array}$ & $\begin{array}{c}5.93 \\
(6.70)\end{array}$ & $\begin{array}{c}12.00 \\
(12.46)\end{array}$ & 472.93 & 65.33 \\
\hline $\mathrm{NiB} 2$ & Pale green & $118 \mathrm{dec}$. & $\begin{array}{c}22.48 \\
(23.24)\end{array}$ & $\begin{array}{c}2.73 \\
(3.81)\end{array}$ & $\begin{array}{c}11.67 \\
(12.05)\end{array}$ & $\begin{array}{c}6.56 \\
(6.88)\end{array}$ & $\begin{array}{c}12.13 \\
(12.61)\end{array}$ & 464.70 & 93.32 \\
\hline $\mathrm{CoB} 2$ & Greenish blue & $82 \mathrm{dec}$. & $\begin{array}{c}23.57 \\
(24.10)\end{array}$ & $\begin{array}{c}2.99 \\
(3.79)\end{array}$ & $\begin{array}{c}11.76 \\
(12.51)\end{array}$ & $\begin{array}{c}6.31 \\
(7.15)\end{array}$ & $\begin{array}{c}12.29 \\
(13.16)\end{array}$ & 447.00 & 76.21 \\
\hline
\end{tabular}

Where: $d=$ decomposition degree,$M=$ metal 


\section{Theoretical calculation}

HyperChem-8 can plot orbital functions resulting from semiempirical quantum mechanical calculation, as well as the electrostatic potential. The total charge density or the total spin density can also be determined during a semi-empirical calculation. This information is useful in determining reactivity and correlating calculation results with experimental data. Hyper Chem offers ten semi-empirical molecular orbital methods, with options for organic and main group compounds, for transition metal complexes and spectral simulation[6]. PM3 level of semiempirical method was used for calculation the heat of formation $\left(\Delta \mathrm{H}^{\circ} f\right)$ and binding energy $\left(\Delta \mathrm{E}_{\mathrm{b}}\right)$ for all metal complexes.Electrostatic potential ,HOMO,and LUMO for ligands B1, and B2 calculated by using this program.

\section{Results and Discussion:}

The elemental analysis showed 1:1(metal:ligand) stoichiometry for the complexes .The analytical data together with some physical properties of the complexes are summarized in Table (1).They agree well with the formula $\mathrm{ML}\left(\mathrm{NO}_{3}\right)_{2} \cdot \mathrm{nH}_{2} \mathrm{O}$ (whereM=Ni(II) and $\mathrm{Co}(\mathrm{II}), \mathrm{L}=2-$

benzamidobenzothiazole(B1), and 2actamidobenzothiazole $\quad(\mathrm{B} 2)=\mathrm{n}=1-$ 2.The complexes were insoluble in common organic solvents, but soluble in DMF and DMSO. The molar conductance values of the complexes indicate their 1:1 electrolytic nature.

\section{1-IR spectra}

The IR spectra of the ligands are complicated due to the large number of the groups which have overlapping regions, howeverfew bands have been selected in order to observe the effect of complexation.The structurally significant IR bands for the free ligands (B1and B2), and their complexes are listed in Table (2).The spectrum of free ligand (B1) shows strong bands at $1674,1450,1257$, and $1651 \mathrm{~cm}^{-1}$ assigned to amide (I), amide(II), amide (III), and $\quad(\mathrm{C}=\mathrm{N} \quad)$ respectively[5], while the spectrum of the free ligand (B2) exhibits the absorption bands for amide (I), amide(II), amide (III), and (C=N ) at $1697,1446,1269$ and $1651 \mathrm{~cm}^{-1}$ respectively[7], Figures(2,3). The most important difference between the two spectrum is the stretching vibration of amide (I) band appeared at higher frequency in the spectrum of the ligand B2. In the spectra of B1 complexes, the bands due to amide (I) and $(\mathrm{C}=\mathrm{N})$ group show shifts to the lower frequencies $\quad\left(\sim 20-35\right.$ and $\left.\sim 93 \mathrm{~cm}^{-1}\right)$ respectively. These changes indicated that the uncharged amide oxygen and $\mathrm{C}=\mathrm{N}$ groups took part in the coordination. More evidence of the spectra of complexes exhibited new bands assigned to the (M-O), and (M$\mathrm{N})$ at $466-594 . \mathrm{cm}^{-1}$ for $(\mathrm{NiB} 1)$, and 466- $582 \mathrm{~cm}^{-1}$ for CoB1 respectively [8]. The spectrum of B2 complexes also shows shifting of amide $I$ and $\mathrm{C}=\mathrm{N}$ bands to the lower frequencies ( 31 and 27-47 $\mathrm{cm}^{-1}$ ) respectively, suggesting collapse of these groups of the ligand (B2) in the complexes. More evidence of the spectrum also showed new bands due to $\mathrm{M}-\mathrm{O}$, and $\mathrm{M}-\mathrm{N}$ at462- $559 \mathrm{~cm}^{-1}$ for $\mathrm{NiB} 2$, and $424-543 \mathrm{~cm}^{-1}$ for CoB2 respectively[9]. The infrared spectra of all complexes exhibited abroad band at ( 3383-3410) which supports the presence of lacttic held water molecules out of coordination sphere 
Table (2): Infrared spectral bands $\left(\mathrm{cm}^{-1}\right)$ and their assignments of ligands and their metal complexes

\begin{tabular}{|c|c|c|c|c|c|c|c|c|c|}
\hline Com. & $\mathrm{v}\left(\mathrm{H}_{2} \mathrm{O}\right)$ & $\mathbf{v}(\mathrm{NH})$ & $\begin{array}{l}\text { Amide } \\
\text { (I) }\end{array}$ & $v(C=N)$ & $\begin{array}{l}\text { Amide } \\
\text { (II) }\end{array}$ & $\begin{array}{l}\text { Amide } \\
\text { (III) }\end{array}$ & $\begin{array}{l}\text { M- } \\
\text { v(O) }\end{array}$ & $\begin{array}{c}\text { M- } \\
v(N)\end{array}$ & $\overline{\delta \mathrm{H}_{2} \mathrm{O}}$ \\
\hline B1 & --------- & $\begin{array}{c}3294 \\
\text { m }\end{array}$ & $1674 \mathrm{~s}$ & $1651 \mathrm{~s}$ & $\begin{array}{c}1450 \\
\mathrm{~m}\end{array}$ & $\begin{array}{c}1257 \\
\mathrm{~m}\end{array}$ & -------- & -------- & - \\
\hline B2 & ---------- & $\begin{array}{c}3255 \\
\mathrm{~m}\end{array}$ & $1697 \mathrm{~s}$ & $1651 \mathrm{~s}$ & $1446 \mathrm{~s}$ & $\begin{array}{c}1269 \\
\text { sh }\end{array}$ & -------- & -------- & -------- \\
\hline NiB 1 & $\begin{array}{c}3410.15 \\
b\end{array}$ & $\begin{array}{c}3375 \\
b\end{array}$ & $1639 \mathrm{~s}$ & $\begin{array}{c}1558 \\
\mathrm{~m}\end{array}$ & $1450 \mathrm{~m}$ & $\begin{array}{c}1249 \\
\text { W }\end{array}$ & $\begin{array}{l}594 \\
\text { vw }\end{array}$ & $466 \mathrm{~m}$ & $810 \mathrm{w}$ \\
\hline CoB1 & $\begin{array}{c}3390.86 \\
b\end{array}$ & $\begin{array}{c}3350 \\
b\end{array}$ & $1654 \mathrm{~s}$ & $\begin{array}{c}1558 \\
\mathrm{~m}\end{array}$ & $1450 \mathrm{~m}$ & $1257 \mathrm{w}$ & $\begin{array}{l}582 \\
v w\end{array}$ & $466 \mathrm{w}$ & $810 \mathrm{w}$ \\
\hline NiB2 & $\begin{array}{c}3383.14 \\
b\end{array}$ & $\begin{array}{c}3350 \\
b\end{array}$ & $1666 \mathrm{~s}$ & $\begin{array}{c}1604 \\
\mathrm{~m}\end{array}$ & $1430 \mathrm{~s}$ & $\begin{array}{c}1249 \\
\mathrm{~m}\end{array}$ & $\begin{array}{l}559 \\
\mathrm{vw}\end{array}$ & $462 \mathrm{w}$ & $825 \mathrm{w}$ \\
\hline CoB2 & $\begin{array}{c}3400.00 \\
b\end{array}$ & $\begin{array}{c}3282 \\
\mathrm{~b}\end{array}$ & $\begin{array}{c}1666 \\
m\end{array}$ & $\begin{array}{c}1624 \\
\mathrm{~m}\end{array}$ & $1425 \mathrm{~s}$ & $\begin{array}{c}1249 \\
\mathrm{~m}\end{array}$ & $\begin{array}{r}543 \\
\mathrm{vw}\end{array}$ & $424 \mathrm{w}$ & 829 w \\
\hline
\end{tabular}

Where:-m: medium, s: strong, b: broad, sh: sharp, w: weak

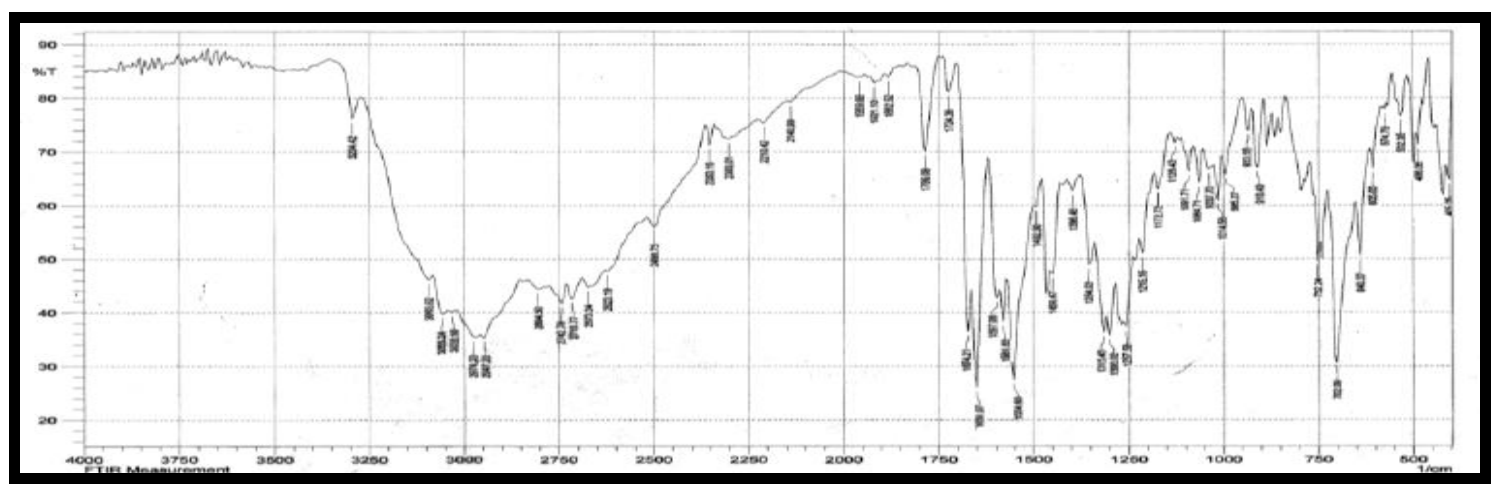

Fig (2): FTIR spectrum of ligand B1

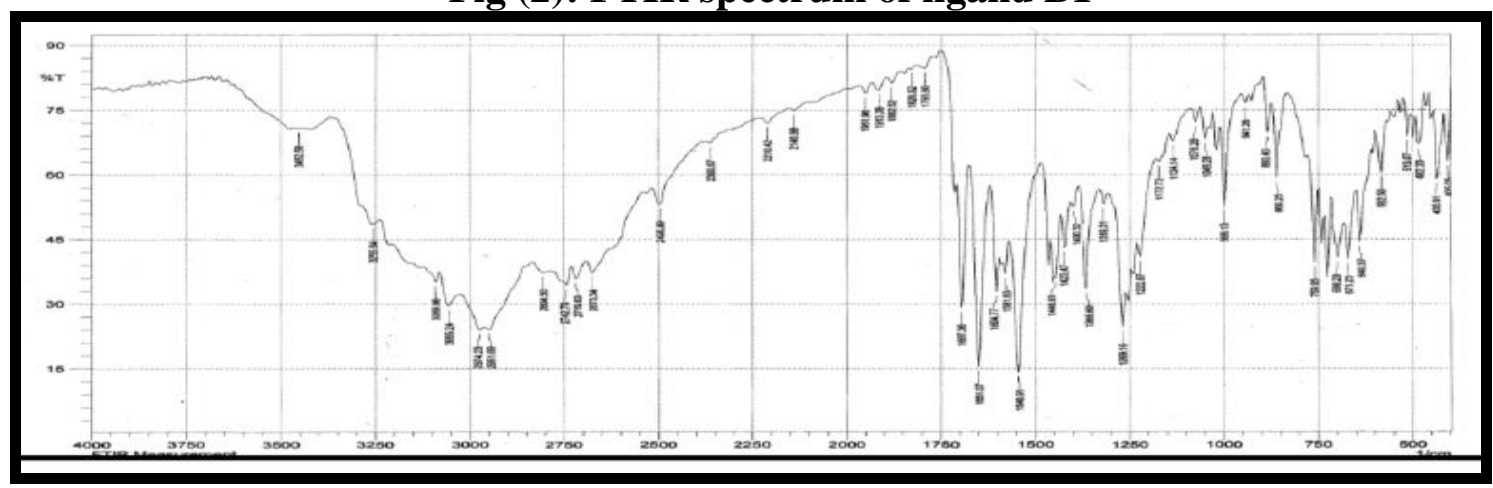

Fig (3): FTIR spectrum of ligand B2

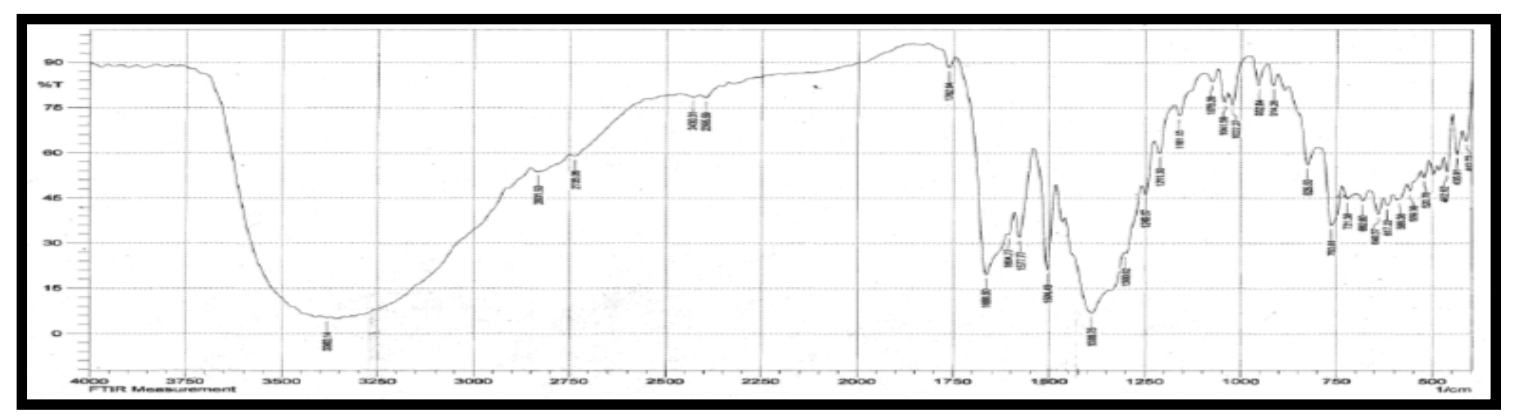

Fig (4): FTIR spectrum of $\mathrm{NiB2}$ 


\section{Electronic spectral and Magnetic 2 -moment studies}

The electronic spectra of ligands $\left(\mathrm{B}_{1}\right.$ and $\mathrm{B}_{2}$ ) exhibits three bands for everyone at $251 \mathrm{~nm}\left(39840 \mathrm{~cm}^{-1}\right)$ $272 \mathrm{~nm}\left(36764 \mathrm{~cm}^{-1}\right), 301 \mathrm{~nm}\left(33222 \mathrm{~cm}^{-}\right.$ $\left.{ }^{1}\right)$, and $243 \mathrm{~nm}\left(41152 \mathrm{~cm}^{-}\right.$ ${ }^{1}, 269 \mathrm{~nm}\left(37147 \mathrm{~cm}^{-1}\right.$, and $298 \mathrm{~nm}$ (33557) $\mathrm{cm}^{-1}$ for $\mathrm{B}_{1}$ and $\mathrm{B}_{2}$ respectively. These bands may be due to $\pi \rightarrow \pi^{*}$, and $n \rightarrow \pi^{*}$ respectively. The electronic spectra of the complexes showed, as expected, different absorptions from that of the free ligands. The green colour of NiB1 complex is postulated to be distorted octahedral with their respective values. The spectrum of (NiB1)complex exhibits bands in the region 27472 , and $18761 \mathrm{~cm}^{-1}$, which are assigned to the ${ }^{3} \mathrm{~A}_{2} \mathrm{~g} \rightarrow{ }^{3} \mathrm{~T}_{1} \mathrm{~g}_{(\mathrm{P})} \mathrm{v}_{3}$, and ${ }^{3} \mathrm{~A}_{2} \mathrm{~g} \rightarrow{ }^{3} \mathrm{~T}_{1} \mathrm{~g}_{(\mathrm{F})} v_{2}$, transitions [5]. The band at $14814 \mathrm{~cm}^{-1}$ may be assigned to the spin forbidden transition ${ }^{3} \mathrm{~A}_{2} \mathrm{~g}$ $\rightarrow{ }^{1} \mathrm{Eg}$. The value of the first transition $v_{1}$ was calculated using Tanaba Sugano diagram. The spectrum also exhibits a charge transfer bands at 36900, and $32573 \mathrm{~cm}^{-1}$. The electronic spectrum of pale green NiB2 Complex was identical with the spectrum of NiB1 complex, which shows bands at 26666 , and $18691 \mathrm{~cm}^{-1}$, assigned to ${ }^{3} \mathrm{~A}_{2} \mathrm{~g} \rightarrow{ }^{3} \mathrm{~T}_{1} \mathrm{~g}_{(\mathrm{p})} \quad v_{3}{ }^{\prime}$ and, ${ }^{3} \mathrm{~A}_{2} \mathrm{~g} \rightarrow{ }^{3}$

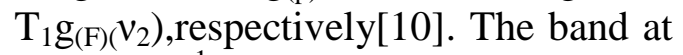
$14084 \mathrm{~cm}^{-1}$ was due to spin forbidden transition ${ }^{3} \mathrm{~A}_{2} \mathrm{~g} \rightarrow{ }^{1} \mathrm{Eg}$. The value of first transition $v_{1}$ was calculated. The spectrum also exhibits a charge transfer band at $34482 \mathrm{~cm}^{-1}$. The octahedral geometry of $\mathrm{NiB}_{1}$, and $\mathrm{NiB}_{2}$ complexes is further supported by the value of the $v_{2} / v_{1}$ ratio, which are 1.64 for both complexes[5].

The nickel complexes have a magnetic moment in the range (3.32-
3.34)B.M, reveals a spin free octahedral configuration. The electronic spectrum of CoB1 complex exhibits three bands at 17857,16420 , and $14947 \mathrm{~cm}^{-1}$ due to the third transitionv $v_{3}$. The value of second transition ${ }^{4} \mathrm{~A}_{2} \rightarrow{ }^{4} \mathrm{~T}_{1(\mathrm{~F})\left(\mathrm{V}_{2}\right) \text { was }}$ calculated theoretically and found equal to $5147 \mathrm{~cm}^{-1}$ using the following equation[5] :-

$$
B^{\prime}=v_{3}+v_{2}-3 v_{1} / 15
$$

The first transition ${ }^{4} \mathrm{~A}_{2} \rightarrow{ }^{4} \mathrm{~T}_{2}\left(v_{1}\right)$ could not be observed since it is expected to appear in a range out of instrument scale so it was calculated from infrared spectrum, and found to be $3400 \mathrm{~cm}^{-1}$.The electronic spectrum of greenish blue $\mathrm{Co}$ (II) (CoB2) complex was identical with spectrum of CoB1 complex also exhibits three bandsat17699,16433, and $15015 \mathrm{~cm}^{-1}$ due to third transition $v_{3}$. The value of second transition ${ }^{4} \mathrm{~A}_{2} \rightarrow{ }^{4} \mathrm{~T}_{1(\mathrm{~F})\left(\mathrm{V}_{2}\right)}$ calculated and found equal to $5033 \mathrm{~cm}^{-1}$ using the same equation above The value of first transition ${ }^{4} \mathrm{~A}_{2} \rightarrow{ }^{4} \mathrm{~T}_{2}\left(v_{1}\right)$ was calculated using Infrared spectrum. The magnetic moment in the range of (4.55-4.61) B.M for the Co(II)complexes suggests a high spin arrangement $[11,12]$. The value of $\beta$ for all prepared complexes was calculated and found quit low (0.72-0.78) suggests a considerable covalent bonding between the metal ion and ligand atoms. The molar conductivity measurement suggests ionic character for all the complexes. The values of $\mathrm{B}^{\prime}$, $\mathrm{Dq}$, and $15 \mathrm{~B}$ for all complexes were calculated, Table (3).According to these data and that obtained from FTIR, C.H.N.S, as well as Atomic absorption and Molar ratio the following structures can be suggested. 


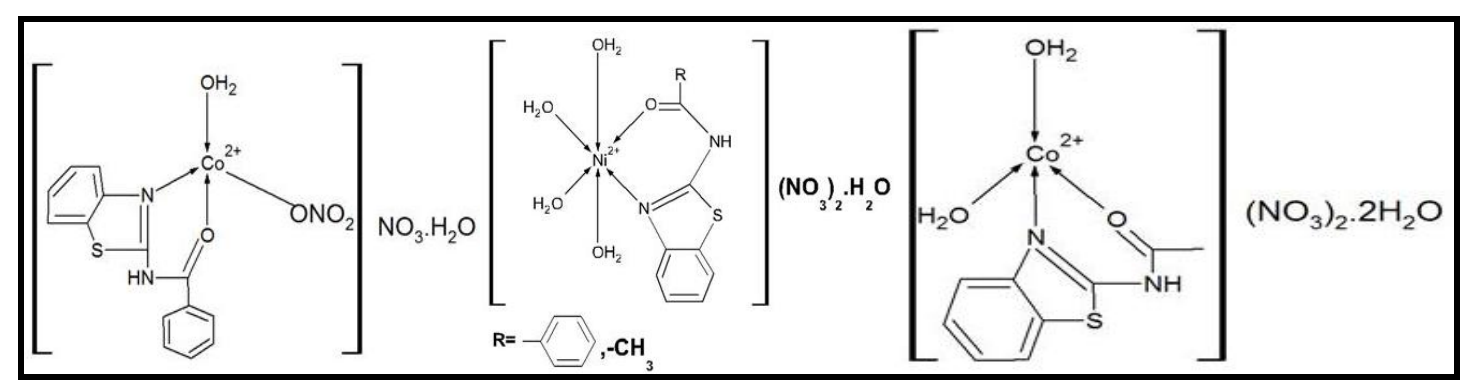

Fig (5): The proposed structure of the prepared complexes.

Table(3):Electronic spectra, magnatic moment, and Molar conductivity for the prepared metal complexes.

\begin{tabular}{|c|c|c|c|c|c|c|c|c|c|c|}
\hline Comp. & $\underset{1}{\text { Bands } \mathrm{cm}^{-}}$ & Assignment & ${ }^{\circ} \mathbf{B}$ & $\mathbf{B}^{\prime}$ & $\boldsymbol{\beta}$ & Dq & $15 B^{\prime}$ & $\begin{array}{c}\mu \\
\text { effect } \\
\text { B.M } \\
\end{array}$ & 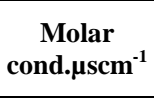 & $\begin{array}{c}\text { Suggested } \\
\text { structure }\end{array}$ \\
\hline NiB1 & $\begin{array}{c}1433 \text { (cal) } \\
18761 \\
27472 \\
36900 \\
32573 \\
\end{array}$ & $\begin{array}{c}{ }^{3} \mathrm{~A}_{2} \mathrm{~g} \rightarrow{ }^{3} \mathrm{~T}_{2} \mathrm{~g} \\
{ }^{3} \mathrm{~A}_{2} \mathrm{~g} \rightarrow{ }^{3} \mathrm{~T}_{1} \mathrm{~g}_{(\mathrm{F})} \\
{ }^{3} \mathrm{~A}_{2} \mathrm{~g} \rightarrow{ }^{3} \mathrm{~T}_{1} \mathrm{~g}_{(\mathrm{P})} \\
\text { ILCT } \\
\text { ILCT }\end{array}$ & 1035 & 772.4 & 0.74 & 1143 & 795 & 3.32 & 119 & Octahedral \\
\hline $\mathrm{CoB} 1$ & $\begin{array}{c}3400 \\
5147 \text { (calc.) } \\
16408 \text { (av.) } \\
\end{array}$ & $\begin{array}{c}{ }^{4} \mathrm{~A}_{2} \rightarrow{ }^{4} \mathrm{~T}_{2} \\
{ }^{4} \mathrm{~A}_{2} \rightarrow{ }^{4} \mathrm{~T}_{1(\mathrm{~F})} \\
{ }^{4} \mathrm{~A}_{2} \rightarrow{ }^{4} \mathrm{~T}_{1(\mathrm{P})}\end{array}$ & 970 & 757.0 & 0.78 & 378.5 & 11100 & 4.55 & 87.1 & Tetrahedral \\
\hline NiB2 & $\begin{array}{c}1190 \text { (cal) } \\
18691 \\
26666 \\
34482 \\
\end{array}$ & $\begin{array}{c}{ }^{3} \mathrm{~A}_{2} \mathrm{~g} \rightarrow{ }^{3} \mathrm{~T}_{2} \mathrm{~g} \\
{ }^{3} \mathrm{~A}_{2} \mathrm{~g} \rightarrow{ }^{3} \mathrm{~T}_{1} \mathrm{~g}_{(\mathrm{F})} \\
{ }^{3} \mathrm{~A}_{2} \mathrm{~g} \rightarrow{ }^{3} \mathrm{~T}_{1} \mathrm{~g}_{(\mathrm{P})} \\
\text { ILCT } \\
\end{array}$ & 1035 & 746.6 & 0.72 & 1119 & 11190 & 3.34 & 107 & Octahedral \\
\hline $\mathrm{CoB} 2$ & $\begin{array}{c}3420 \\
5033 \text { (calc.) } \\
16387 \text { (av.) }\end{array}$ & $\begin{array}{c}{ }^{4} \mathrm{~A}_{2} \rightarrow 4 \mathrm{~T}_{2} \\
{ }^{4} \mathrm{~A}_{2} \rightarrow 4 \mathrm{~T}_{1(\mathrm{~F})} \\
{ }^{4} \mathrm{~A}_{2} \rightarrow 4 \mathrm{~T}_{1(\mathrm{P})}\end{array}$ & 970 & 744.1 & 0.76 & 364.5 & 11160 & 4.61 & 115.5 & Tetrahedral \\
\hline
\end{tabular}




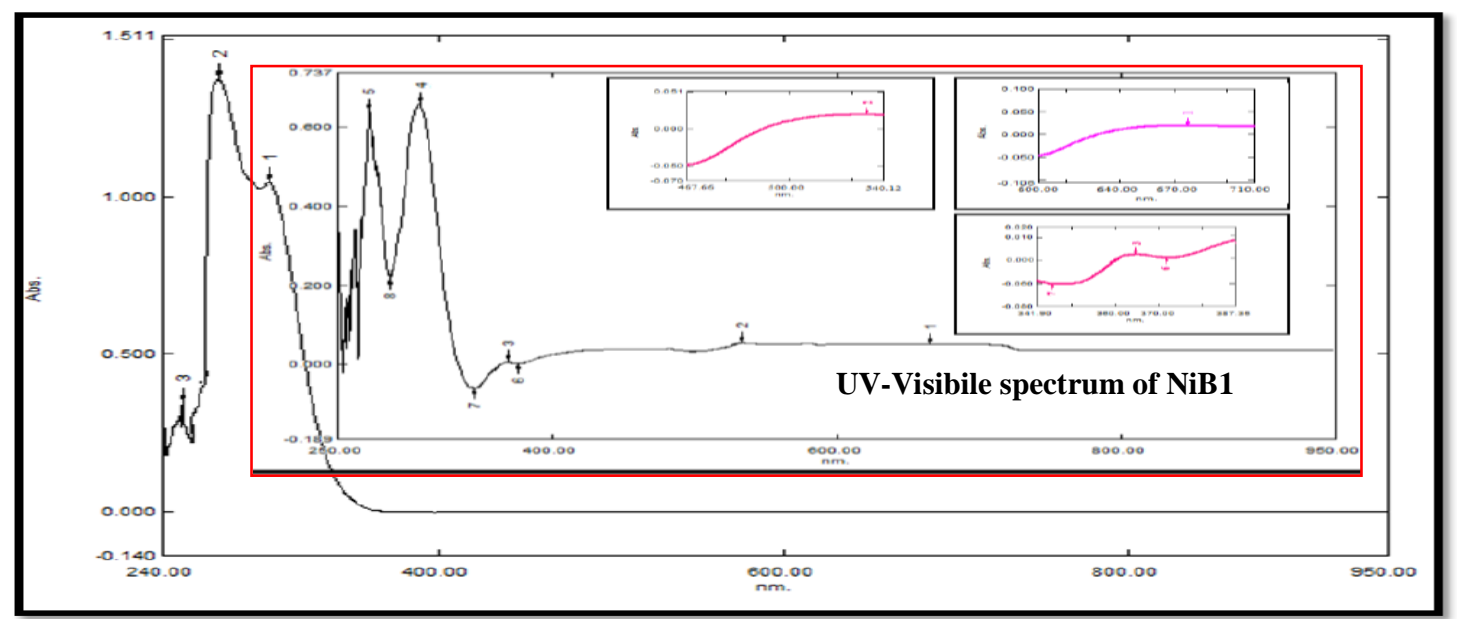

Fig (6):Electronic spectrum of B1and

NiB1

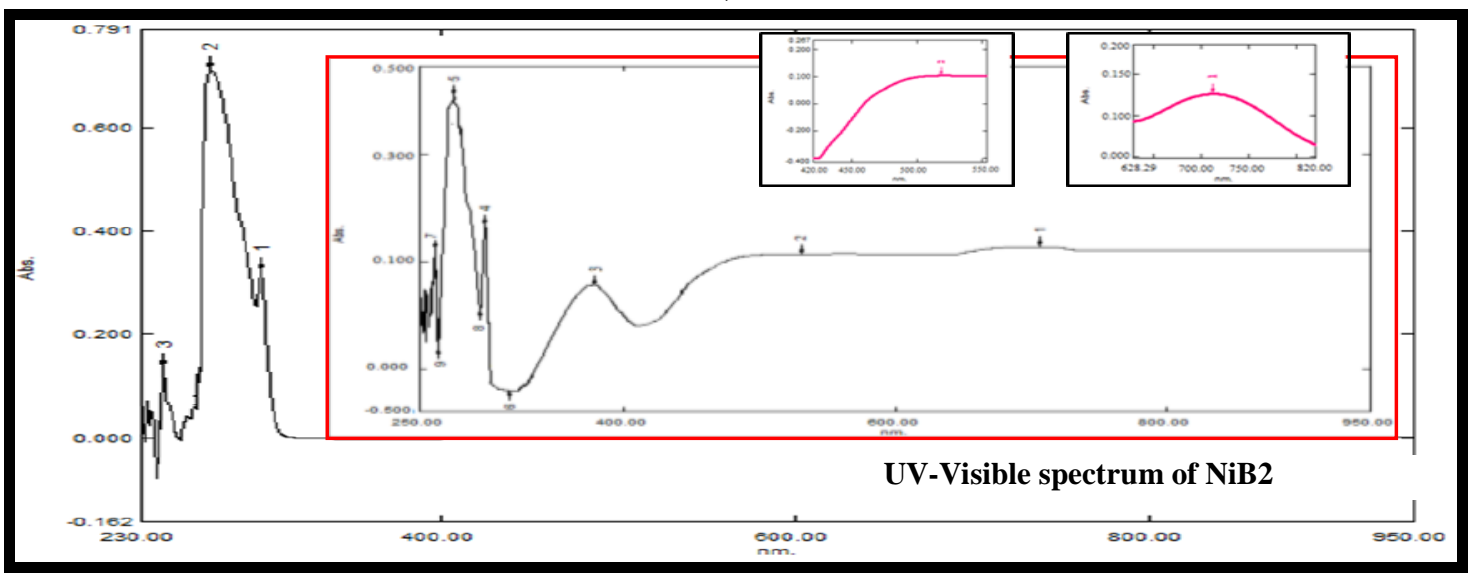

Fig (7):Electronic spectrum of $\mathrm{B} 2$ and NiB2

\section{Study of complexes formation} in solution:

Complexes of ligands $\mathrm{B}_{1}$, and $\mathrm{B} 2$ with metal ions were studied in solution using ethanol as a solvent in order to determine $[\mathrm{M} / \mathrm{L}]$ ratio in the complexes following molar ratio method[13]. A series of $\mathrm{s}$ solutions were prepared having a constant concentration $\left(10^{-3} \mathrm{M}\right)$ of metal ion and ligand .The $[\mathrm{M} / \mathrm{L}]$ ratio determined from the relationship between the absorption of the absorbed light and the mole ratio of $[\mathrm{M} / \mathrm{L}]$. The results of complexes in ethanol suggest that the metal to ligand ratio was [1:1] for all complexes which were similar to that obtained from solid state study.

\section{Theoretical treatment}

The program Hyper chem- 8 was used for semi -empirical molecular mechanic calculation .The heat of formation $\quad \Delta \mathrm{H}^{\circ} \mathrm{f}, \quad$ binding energy $\left(\Delta \mathrm{E}_{\mathrm{b}}\right)$ and dipole moment $(\mu)$ for free ligands and complexes were calculated by PM3, and ZINDO/1 methods, Tables (4), and(5). Also PM3 was used for evaluating the vibrations of new ligands (B1 and B2), Table (6) compares the theoretically calculated wave numbers with experimental values. 
Table(4): The calculated energies(in $\mathrm{KJmol}^{-1}$ ) and dipole moment (in Debye) for ligand $\mathrm{B} 1$ and its complexes

\begin{tabular}{|c|c|c|c|c|c|c|}
\hline Comp. & \multicolumn{3}{|c|}{ PM3 } & \multicolumn{3}{c|}{ ZINDO/1 } \\
\hline & $\Delta \mathbf{H}^{\circ} \mathbf{f}$ & $\Delta \mathbf{E}_{\mathbf{b}}$ & $\boldsymbol{\mu}$ & $\Delta \mathbf{H}^{\circ} \mathbf{f}$ & $\Delta \mathbf{E}_{\mathbf{b}}$ & $\boldsymbol{\mu}$ \\
\cline { 2 - 7 } $\mathbf{B}_{\mathbf{1}}$ & 208.81 & -13447.79 & 3.21 & -26628.05 & -40290.65 & 4.12 \\
\hline NiB1 & -239.35 & -17072.81 & 6.17 & -31132.73 & -47966.18 & 7.65 \\
\hline CoB1 & -537.96 & -14923.44 & 2.61 & -28372.56 & -43833.98 & 8.42 \\
\hline
\end{tabular}

Table(5): The calculated energies(in $\mathrm{KJmol}^{-1}$ ) and dipole moment (in Debye) for ligand $\mathrm{B}_{2}$ and its complexes.

\begin{tabular}{|l|c|c|c|c|c|c|}
\hline Comp. & \multicolumn{3}{|c|}{ PM3 } & \multicolumn{3}{c|}{ ZINDO/1 } \\
\hline \multirow{2}{*}{ B2 } & $\Delta \mathbf{H}^{\circ} \mathbf{f}$ & $\Delta \mathbf{E}_{\mathbf{b}}$ & $\boldsymbol{\mu}$ & $\Delta \mathbf{H}^{\circ} \mathbf{f}$ & $\Delta \mathbf{E}_{\mathbf{b}}$ & $\boldsymbol{\mu}$ \\
\cline { 2 - 7 } & 59.90 & -9591.69 & 3.61 & -18526.91 & -28178.50 & 3.66 \\
\hline NiB2 & -287.99 & -13110.44 & 6.24 & -22875.76 & -35698.20 & 4.54 \\
\hline CoB2 & -363.84 & -11086.54 & 2.97 & -20909.49 & -32359.89 & 8.48 \\
\hline
\end{tabular}

As shown in Tables4 and 5, the binding energy and energy required for formation of the compounds can be arranged as follows:

$1-\Delta \mathrm{H}^{\circ} \mathrm{f}\left(\mathrm{NiB}_{1}\right)<\Delta \mathrm{H}^{\circ} \mathrm{f}\left(\mathrm{B}_{1}\right), \Delta \mathrm{H}^{\circ} \mathrm{f}$

$\left(\mathrm{CoB}_{1}\right)<\Delta \mathrm{H}^{\circ} \mathrm{f}\left(\mathrm{B}_{1}\right)$

$2-\Delta \mathrm{E}_{\mathrm{b}}\left(\mathrm{NiB}_{2}\right)<\Delta \mathrm{E}_{\mathrm{b}}\left(\mathrm{B}_{2}\right), \Delta \mathrm{E}_{\mathrm{b}}\left(\mathrm{CoB}_{2}\right)<$ $\Delta \mathrm{E}_{\mathrm{b}}\left(\mathrm{B}_{2}\right)$

The relationships above explained that the heat formation of complexes is smaller than that for ligands and the binding energy also is smaller than it is for ligands, thus we expected that the complexes are to be thermodynamically more stable than ligands.

Optimization geometry energies and vibrational for free ligands B1, and B2
The result of PM3 method of calculations in gas phase for the heat of formation ,binding energy , and dipole moment of new benzothiazole derivatives were tabulated in Tables (4), and(5). The vibration spectra of free ligands have been calculated, as shown in Table (6). The theoretically calculated wave number for the ligands (B1\&B2) shows the same deviations from the experimental values .These deviations are generally acceptable in theoretical calculations. The most diagnostic calculated vibrational frequencies were chosen for the assignment of ligands which are included in Table (6), Figures (9), and(10).

Table (6): Comparison of experimental and theoretical vibration frequencies for free ligands(B1 and B2).

\begin{tabular}{|c|c|c|c|c|}
\hline Symb. & $\mathbf{v}(\mathbf{N}-\mathbf{H})$ & vAmide(I) & $\mathbf{v}(\mathbf{C}=\mathbf{N})$ & vAmideII \\
\hline \multirow{3}{*}{ B1 } & $3294.42^{*}$ & $1674.21^{*}$ & $1651.07 *$ & $1450.47 *$ \\
& $3314.98^{* *}$ & $1903.14 * *$ & $1649.17 * *$ & $1439.19 * *$ \\
& $(0.6)^{* * *}$ & $(13) * * *$ & $(-0.1)^{* * *}$ & $(-0.7)^{* * *}$ \\
\hline \multirow{3}{*}{ B2 } & $3255.84 *$ & $1697.36^{*}$ & $1651.07 *$ & $1446.77^{*}$ \\
& $3345.87 * *$ & $1941.85^{* *}$ & $1638.88^{* *}$ & $1401.64 * *$ \\
& $(2.6)^{* * *}$ & $(14)^{* * 8}$ & $(-0.7)^{* * *}$ & $(-3.1)^{* * *}$ \\
\hline
\end{tabular}

Where *: Experimental frequency, **: Theoretical frequency

***: Error\% due to main different in the experimental measurements and theoretical treatment of vibrational spectra 
Electronic potential (E.P)

The electrostatic potential (E.P.) describes the interaction of energy of the molecular system with a positive point charge.(E.P) of the ligands were plotted as two and three dimension contours to investigate the reactive sites of the molecules. Also, one can interpret the stereochemistry and rates of many reactions involving soft electrophiles and nuclephiles in terms of the properties of frontier orbital's (HOMO and LUMO).Overlap between the HOMO and LUMO is a governing factor in many reactions. The HOMO and LUMO values were plotted in three dimension counters to get more information about these molecules Figure (8). The results showed that the LUMO of transition metal ion prefers to react with HOMO of donor atoms of ligands.

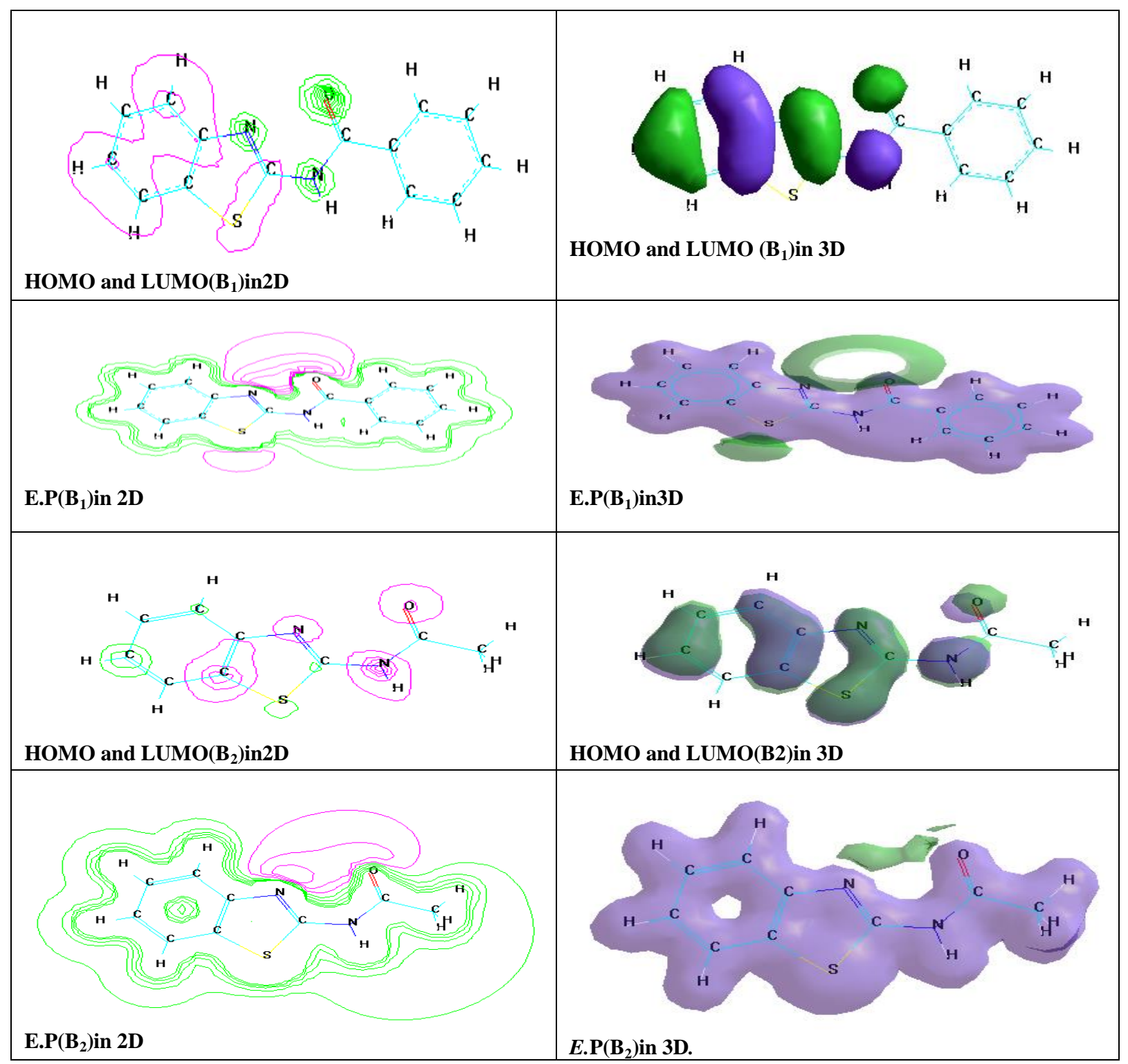

Fig (8):HOMO, LUMO and Electrostatic potential as 2Dand 3D counters for free ligands. 


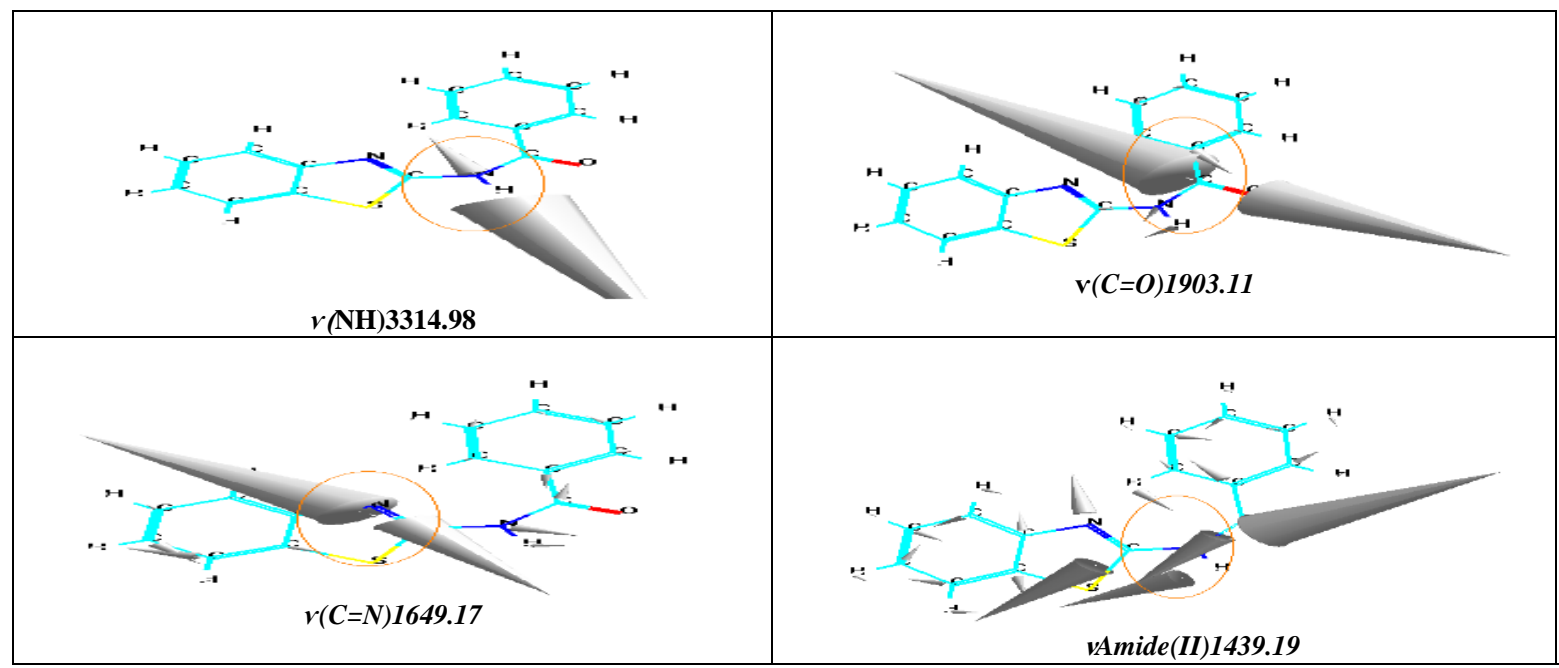

Fig (9):Calculated vibrational frequencies of 2-(benzamido) benzothiazole(B1)

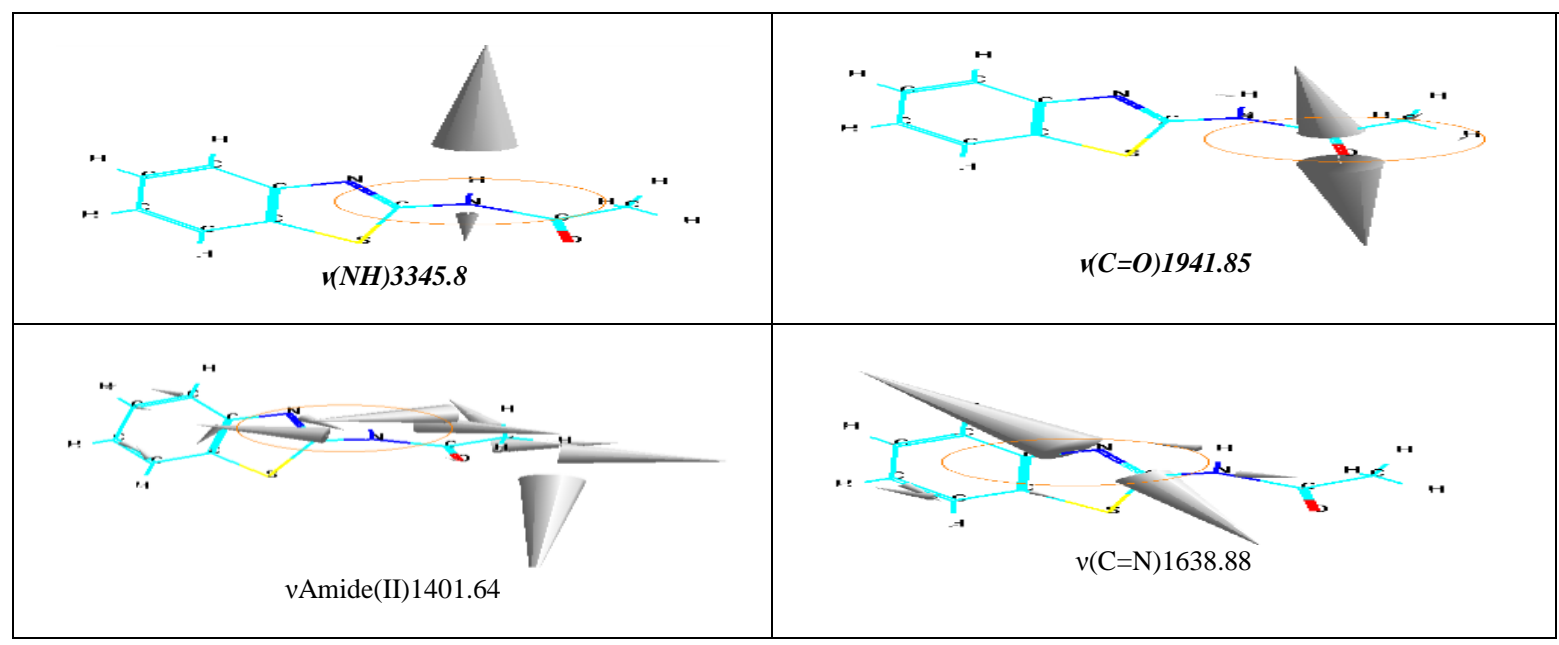

Fig (10): Calculated vibrational frequencies of 2-(actamido) benzothiazole(B2)

\section{Conclusion}

The ligands behave as a bidenetate chelating with oxygen and nitrogen atoms, to form an octahedral geometry for the nickel complexes and a tetrahedral geometry for the cobalt complexes, . The theoretical calculation data of the frequencies for the ligands and their complexes agreed and help to assign an ambiguously the most diagnostic bands.

\section{References:}

1. Premlata,Verma .S and seth. G. 2012. Synthesis, Characterization and Antimicrobial Activity of $\mathrm{Ni}(\mathrm{II})$ Complexes with substituted
Benzothiazole ligands\& Amino acids, RJPBCS.3(1):435-443.

2. Rana .A,Siddiqui. N,khan.S,Haque. S. and Bhat. M.(2008). Synthesis and pharmacological evalution of .N-\{[6-substituted-1,3-benzothiazole -2-yl) amino ]carbonthioyl\} 2/4substituted benzomides. Eur.J.Med. Chem. 43:1114-1122.

3. Huang. W., and Yang.G. 2006. Microwave- assisted one-pot synthesis and fungicidal activity. Polyh. 19:689-693.

4. a)-Ram,V,Singha. Vand Guru. P.1990.Synthesis of pyrimidines and azolopyrimidinesasleishmanicides.E ur.J.Med.Chem.2(6):533-538. 
b- Yousif. E, Adil .Hand Farina .Y. 2010. Synthesis and Characterization of some Metal Ions with 2-amino Acetate Benzothiazole. J. Appl. Scien. Res. 6(7):779-882.

5. Gudasi. K,Patil. S.A, Vadavi. R.S, Shenoy. R.V and Patil. M.S. 2006.Synthesis and spectral studies of $\mathrm{Cu}(\mathrm{II}), \mathrm{Ni}$ (II), $\mathrm{Co}(\mathrm{II}), \mathrm{Mn}$ (II), $\mathrm{Zn}$ (II) and $\mathrm{Cd}(\mathrm{II})$ complexes of new macro cyclic ligand N,N-bis(2benzothiazolyl)-2,6-pyridine dicarboxamide. J. Serb. Chem. Soc. 71(5):529-542.

6. Foresman. J, and C. Frish, (1996). Exploring chemistry with Electronic structure methods. GaussianInc, $2^{\text {nd }}$. Ed., Pittsburgh, PA, Page 232.

7. Sharma. S, Sharma. A.K, Singh.O, Kumar. U.S, and Sharma. A.K .2011.synthesis and anti-tubercular activity of n,n'-bis(benzothiozolyl)2,6-pyridinedicarboxamide. IJPPR. (2): 351-354.

8. Kulkarni. A.D, Patil. S.A and Badami.P.S.2009. Electrochemical Properties of some Transition Metal Complexes: Synthesis, Characterization and In-vitro antimicrobial studies of $\mathrm{Co}(\mathrm{II})$, $\mathrm{Ni}(\mathrm{II}), \quad \mathrm{Cu}(\mathrm{II}), \quad \mathrm{Mn}(\mathrm{II}), \quad$ and $\mathrm{Fe}(\mathrm{III})$ Complexes.Int.J.Elec.Chem.S ci.4:717-729.
9. Ibrahim .K.M, Zaky, R. RGomaa. E.A, El-Hady. M.N .2011.Spectral, Magnetic, Thermal studies and Antimicrobial activity of (E)-3-(2Benzylidenehydrazinyl)-3-OXO-N(Thiazol-2-yl) Propanamide complexes. RJPBCS. 2(3):391-404.

10. Srinivasan. R.S.R, sougandi. I, venkatesan. R. and Sambasiva rao.P.2003.Synthesis androom temperature single crystal EPRstudies of di nickel complex having an $\left\{\mathrm{Ni}_{2}(\mu-\text { phenoxide })_{2}\right\}^{+2}$ unit supported by a macrocyclic ligand eniornment $\left\{\mathrm{Ni}_{2}(\mathrm{~L})_{2}\right.$ $\left(\mathrm{OCLO}_{3}\right] \quad[\mathrm{L}=-$-[4-methyi-pyridin-2yl amino) -methyl] phenol. Proc.Ind. Acad.Sci.(Chem.Sci).115:2:91-102.

11. Nicholls. D.1973 "The chemistry of the Iron, Cobalt and Nickel" Pergman press, Oxford, Page 514.

12. Thakar. A.S.,Pandya. K.S., Joshi. K.T. and Pancholi. A.M. 2011.Synthesis ,characterization and Antibacterial Actlvity of Novel Schiff Bases Derived from 4phenyl-2-aminothiazole and their $\mathrm{Mn}(\mathrm{II}), \mathrm{Fe}(\mathrm{II}), \mathrm{Co}(\mathrm{II}), \mathrm{Ni}(\mathrm{II})$, and $\mathrm{Cu}(\mathrm{II})$ metal complexes .EJ.Chem.8(4):1556-1565.

13. Doglas,s., Donaldw.,Holler F, and Crouch S.(2004).Fundamentals of Analytical Chemistry. Saunders College $8^{\text {th }}$ ed, New York, Page 345. 


\title{
تحضير ودراسة طيفية ومعالجة نظرية لمعقدات النيكل الثنائي والكوبلت

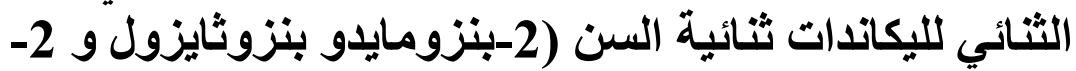

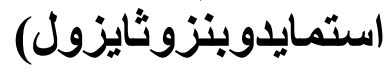

\author{
* أمينة نعيم صيوان
}

\author{
محاسن فيصل الياس*
}

*قنم الكيمياء- كلية العلوم للبنات- جامعة بغداد/العر اق-بغداد.

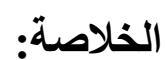

جرى تحضير معقدات جديدة لليكاند 2-بنزمايدوبنزونايزول و الليكاند2-استمايدوبنزوثنايزول مع ايونات التات العناصر

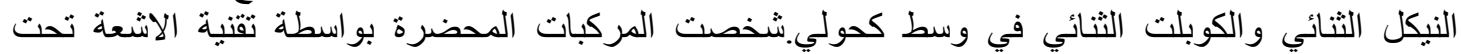

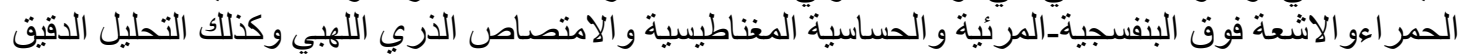

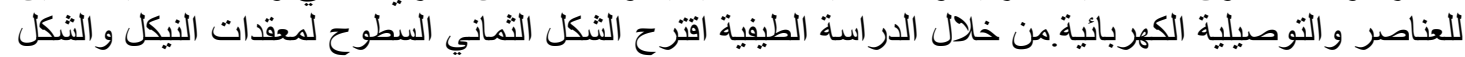

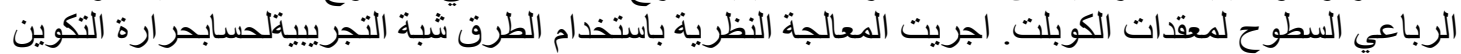

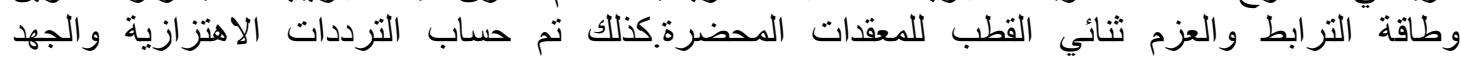

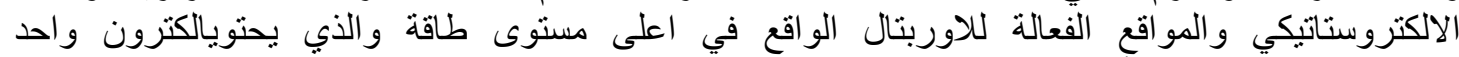

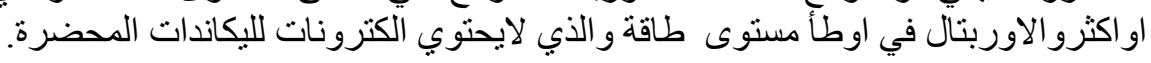

